\title{
NEW STUDIES AND RESEARCH RESULTS ON GOVERNANCE AND FINANCE IN THE BRAZILIAN AND LATIN AMERICA CONTEXTS
}

\author{
ANTONIO ZORATTO SANVICENTE ${ }^{1}$ \\ (iD) https://orcid.org/0000-0002-2888-8318 \\ EDUARDO KAZUO KAYO ${ }^{2}$ \\ https://orcid.org/0000-0003-1027-8746 \\ MANUEL JOSÉ DA ROCHA ARMADA ${ }^{3}$ \\ (iD) https://orcid.org/0000-0002-2301-1752 \\ WILSON TOSHIRO NAKAMURA ${ }^{4}$ \\ (iD) https://orcid.org/0000-0002-4697-5685
}

We are pleased to publish this special edition of the Revista Administração Mackenzie (RAM) on corporate finance and governance. We have selected six articles, addressing different themes and methodologies analysis. These writings cover relevant topics in the finance and governance context, while also embracing research in the more specific field of behavioral finance. This edition also reflects the interest of many researchers in corporate governance, addressing topics such as an analysis of corporate governance codes in the international context, as well as characteristics and composition of boards of

\footnotetext{
Getulio Vargas Foundation (FGV), São Paulo, SP, Brazil.

2 University of São Paulo (USP), São Paulo, SP, Brazil.

3 University of Minho, School of Economics and Management - NIPE (Research Center), Braga, Portugal.

4 Mackenzie Presbyterian University (UPM), São Paulo, SP, Brazil.
}

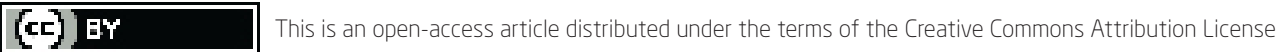

\footnotetext{
This paper may be copied, distributed, displayed, transmitted or adapted for any purpose, even commercially, if provided, in a clear and explicit way, the name of the journal, the edition, the year and the pages on which the paper was originally published, but not suggesting that RAM endorses paper reuse. This licensing term should be made explicit in cases of reuse or distribution to third parties.

Este artigo pode ser copiado, distribuído, exibido, transmitido ou adaptado para qualquer fim, mesmo que comercial, desde que citados, de forma clara e explícita, o nome da revista, a edição, o ano e as páginas nas quais o artigo foi publicado originalmente, mas sem sugerir que a RAM endosse a reutilização do artigo. Esse termo de licenciamento deve ser explicitado para os casos de reutilização ou distribuição para terceiros.
} 
directors in the Brazilian context. We hope everyone can take good advantage of the readings. In the paragraphs bellow, we summarize the articles that are part of this edition.

Kelmara Mendes Vieira, Vanessa Martins Valcanover, Ani Caroline Grigion Potrich and Everton Anger Cavalheiro are the authors of the article entitled "My business and I: Entrepreneur personality traits and capital structure choice". They examine how personality traits of entrepreneurs can influence the capital structure of micro and small private companies in Brazil. To pursue this objective, they analyzed 625 companies located in Rio Grande do Sul and, through confirmatory factor analysis and structural equation modeling, found results that suggest direct and indirect relationships between the entrepreneur's characteristics and the capital structure of their companies. In particular, some of the most important findings suggest that gender and personal attitude towards debt directly affect companies' capital structure.

Lucas Nogueira Cabral de Vasconcelos and Orleans Silva Martins are the authors of the article entitled Governance through stock trading in Brazil: evidence with institutional investors. The authors analyze stock trading as an external mechanism of corporate governance and its effect on abnormal returns, information and corporate performance. An important premise in this study is that well-informed institutional investors can incorporate relevant information into stock prices, disciplining managers and, thus, improving company performance. Although the results show that the number of institutional investors does not affect abnormal returns, they increase the incorporation of company-specific information into stock prices, increasing the price efficiency in the stock market.

In the work entitled "Behavioral finance: Empirical evidence using Magic Formula in the Brazilian stock market”, Frederico Dimarzio, Jose Matias Filho and Ricardo Antonio Fernandes investigate, within the context of the Brazilian stock market, the possible informational inefficiency of the shares traded on B3. The aim of the researchers was to explain such inefficiencies in the pricing of stocks traded on the Brazilian stock exchange. They were based on the efficient markets hypothesis and on behavioral finance. The study used data from companies listed on B3 concerning a period of 20 years, which started in 1999. The results found in this study indicate that the Brazilian stock market does not meet the assumptions of the efficient markets hypothesis, since it has been observed that it is possible for agents to obtain superior returns. The authors explain the phenomenon by using the concepts of behavioral finance, in such a way that behavioral biases interfere in the decision making of investors who price the shares incor- 
rectly. Once this limitation of the agents' rationality was identified and explained, the researchers point out that further research is needed on the subject to better understand the stock pricing process in the market.

Sônia Freire Sindeaux dos Santos, Bruno Funchal and Silvania Neris Nossa, in their work on "Irregularities and the market value of companies", examine the possibility that a company with shares traded on B3, when subjected to investigations and sanctions by the Comissão de Valores Mobiliários (CVM), may suffer reductions in their market value. The basic assumption of this paper is that the occurrence of sanctioning proceedings by the regulator (CVM) provides additional information to participants of the stock market. The article focused on detecting alleged irregularities in the accounting data of publicly traded companies that led to sanctioning procedures from 2010 to 2018 period. The empirical results indicate that the proceedings do not provide notable additional information, as the variable that indicates the occurrence of a sanctioning procedure motivated by such irregularities is not significant to explain differences in market value between sanctioned and non-sanctioned companies. In the basic model of the work, the market value was measured by the quotient between the market value and the book value of the company ("Tobin's Q"). The authors, however, recommend that company's directors be concerned with improving governance conditions, as this can mitigate the consequences of the occurrence of a sanctioning proceeding and, mainly, reduce the likelihood that it will occur.

Agnaldo Antonio Santos, Sergio Feliciano Crispim, Eduardo de Camargo Oliva and Marcos Dornelles contribute with the article entitled "Codes of corporate governance of Latin American countries: Analysis of UN practices”. The authors start, as a reference, from corporate governance practices recommended by the United Nations, and proposed themselves to verify if, in a group of Latin American countries (Brazil, Mexico, Argentina, Colombia, Chile and Peru), the governance policies suggested at national level seems to adjust or not to global recommendations. They used content analysis as their methodology. The basic assumption is that the United Nations code is the most appropriate from the point of view of the international investor. In turn, the reference document is represented by the Guide on disclosure of good corporate governance practices, published in 2006 (United Nations Conference on Trade and Development, 2006). Thus, greater adherence to this code in a country would help the attraction of international investment, ceteris paribus. The conclusion reached is that the national governance codes of Brazil, Argentina and Colombia show greater convergence with the global code; in the case of Peru, convergence is partial; finally, convergence is more limited 
in the cases of Chile and Mexico. The content analysis seeks to verify whether the main aspects of governance quality are covered by the codes, specifically: 1. shareholder structure and exercise of control rights; and 2. structure and process of the board of directors.

Tobias Coutinho Parente and Cláudio Antonio Pinheiro Machado Filho contribute with the article entitled "Boards of directors in Brazil: Literature review and research agenda". The objective of the research was to review the existing Brazilian literature on boards of directors, an essential element of corporate governance, and, based on this foundation, to indicate research proposals for future articles. The total of 95 works on the subject published in the period from 2000 to 2019 were analyzed. They observed that these studies dealt mostly with board composition, good governance practices, and gender diversity in the board composition. Such aspects almost always tended to verify their significance as an explanation of differences in performance between companies, noting a small variation between the problems considered and the methods of analysis used. As research gaps, the authors point out the study of psychosocial processes and specific tasks of the board, i.e., they claim that there should be greater attention to how boards work. 